\title{
In the
}

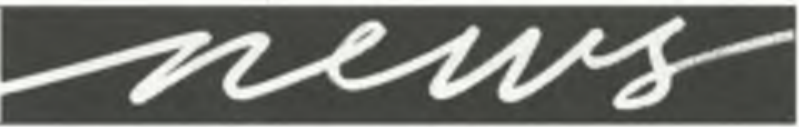

We all continue to be exposed to more and more information with less and less time to read and digest it. The age-old question is how are we to keep up with this exponential growth and proliferation of information?

CERL News has a new mechanism to add to your arsenal of ways to keep up-todate-"Fast Facts." This new column aims to be an "eclectic mix of facts, statistics, quotable quotes, and other information of interest to academic and research librarians." The focus of the column is to "highlight recent information not readily available that is related directly to academic librarianship, higher education, scholarly communication, and other issues of interest to members of the profession and their learning communities."

We are pleased to welcome Ann Viles, coordinator of reference and instruction at Appalachian State University, to our pages as editor of the new "Fast Facts." Ann's 27- year career includes stints at the Universities of Tennessee and Memphis and the Curtis Institute of Music. Ann welcomes your suggestions about what to include in the column, so send your ideas to her at vilesa@conrad.appstate.edu.

To make it easy for you to find, the "Fast Facts" column will appear as the final page of each issue of CGRL News. So flip to the back and check out the tidbits Ann has compiled this month.

Then come back to the rest of the magazine and peruse articles about planning jointuse libraries (page 478), developing information literacy programs (page 483), scholarly communication (page 515), and conducting successful personnel searches (pages 499 and 503). The official ACRL election results are also published in this issue (page 488). Congratulations to ACRL's newly-elected leaders!

- Mary Ellen K. Davis Editor-in-cbief medavis@ala.org

\section{ATLA \\ American Theological Library Association}

\section{What's so exciting about ATLA?}

\author{
Here are just a few things:
}

- RDB: The ATLA Religion Database on CD-ROM-chosen by academic librarians as a favorite CD-ROM product

- Membership: More than 550 individuals and 250 institutions - enjoying the many benefits of membership in ATLA

- ATlas: The ATLA Serials project-linking fifty years of fifty important theological journals to the ATLA Religion Database

- Serials on Microfilm: A collection of nearly 2,000 fully cataloged entries

- ALA воотн: \#2146 at the American Library Association annual conference at McCormick Place in Chicago, July 8-11, 2000 — come visit us! 